\title{
UJI POTENSIAIR REBUSAN CACING TANAH JENIS Perionyx excavates DALAM MENGHAMBAT PERTUMBUHAN BAKTERI Salmonella typhi SECARA Invitro
}

\author{
Ika Maulida Oktafi ${ }^{1}$, Zainal fikri ${ }^{2}$, .Rohmi $^{3}$ \\ ${ }^{1-3}$ Jurusan AnalisKesehatan, PoltekkesKemenkesMataram, Indonesia
}

\begin{tabular}{l}
\hline \hline Article Info \\
\hline Article history: \\
Received Des $13^{\text {th }}, 2017$ \\
Revised Jan $25^{\text {th }}, 2018$ \\
Accepted Feb $28^{\text {th }}, 2018$ \\
\end{tabular}

Keyword:

Perionyx excavatus, Salmonella typhi Typoid Fever

\begin{abstract}
Treatment of diseases using natural ingredients has been carried out in many communities, for example treatment using earthworms. Earthworms have been supported by the community in the treatment of diseases, one of which is typhoid fever. This study was an observational study digging Salmonella typhi bacteria. The method used is the diffusion method so that by means of a well using a sterile aquadest solvent on MHA media. Earthworms that have been boiled then the cooking water is made several concentrations of earthworm stew. The amount of research in this study is 25 handling units including controls. From the results of the research that has been done, it does not include the growth of Salmonella typhi bacteria. So that the processing of soil worms Perionyx excavatus with caradirebus for 15 minutes at $72^{\circ} \mathrm{C}$, is not good in the antibacterial process in earthworms. With the results of this study, it is expected to be a reference by the community in choosing how to process the soil to be used as medicine
\end{abstract}

\begin{abstract}
ABSTRAK
Pengobatan penyakit menggunakan bahan alami sudah banyak dilakukan di masyarakat, contohnya pengobatan menggunakan cacing tanah.Cacing tanah telah dipercaya oleh masyarakat dalam mengobati penyakit, salah satunya adalah penyakit demam tifoid.Penelitian ini merupakan penelitian observasional deskriptif yang bertujuan untuk mengetahui bagaimana potensi cacing tanah jenis Perionyx excavatus dalam menghambat pertumbuhan bakteri Salmonella typhi. Metode yang digunakan adalah metode difusi agar dengan cara sumuran menggunakan pelarut aquadest steril pada media MHA. Cacing tanah yang telah direbus kemudian air rebusannya dibuat beberapa konsentrasiair rebusan cacing tanah.Jumlah perlakuan dalam penelitian ini adalah sebanyak 25 unit perlakuan termasuk kontrol. Dari hasil penelitian yang telah dilakukan, tidak terdapat hambatan terhadap pertumbuhan bakteri Salmonella typhi.Sehingga pengolahan cacing tanah jenis Perionyx excavatus dengan caradirebus selama 15 menit dengan suhu $72^{\circ} \mathrm{C}$, tidak bagus dalam proses pemisahan antibakteri pada cacing tanah. Dengan hasil penelitian ini, diharapkan dapat menjadi acuan oleh masyarakat dalam memilih cara pengolahan cacing tanah untuk dijadikan sebagai obat.
\end{abstract}

Kata kunci: Cacing tanah Perionyx excavatus, Salmonella typhi, demam tifoid

Copyright $\odot$ Jurnal Analis Medika Bio Sains

\section{Pendahuluan}

Penyakit infeksi merupakan salah satu masalah serius dalam dunia kesehatan.Penyakit infeksi merupakan penyakit yang disebabkan oleh mikroba patogen (Darmadi, 2008).Salah satu mikroba patogen yang ada di kehidupan manusia yaitu bakteri Salmonella typhi (Hawley, 2003).Bakteri Salmonella typhi ini menjadi salah satu penyebab penyakit infeksi akut yang dapat menyerang manusia yaitu demam tifoid (Pelczar, 2006).Selain disebabkan oleh bakteri Salmonella typhi secara umum demam tifoid juga disebabkan oleh bakteri Salmonella paratyphi A, B, atau C. Gejala penyakit dari demam tifoid akibat Salmonella paratyphi mirip dengan demam tifoid akibat Salmonella typhi, hanya infeksi yang terjadi mempunyai gejala yang lebih 
ringan (Anonim, 2010). Demam tifoid akibat Salmonella typhi sendiri akan sangat berbahaya jika tidak segara di tangani secara baik dan benar, Menurut data WHO (World Health Organization) memperkirakan angka insidensi demam tifoid di seluruh dunia sekitar 17 juta jiwa per tahun, angka kematian akibat demam tifoid akibat Salmonella typhimencapai 600.000 per tahun dan 70\% dari 600.000 terjadi di Asia.

Daerah endemik demam tifoid tersebar di berbagai benua, mulai dari Asia, Afrika, Amerika Selatan, Karibia, hingga Oceania. Sebagain besar kasus (80\%) ditemukan di negara-negara berkembang, seperti Bangladesh, Laos, Nepal, Pakistan, India, Vietnam, dan termasuk Indonesia (Brusch,J.L, 2010). Pada minggu ke-8 tahun 2016 Penyakit demam tifoid termasuk ke dalam tiga jenis penyakit dengan peringatan dini berpotensi KLB yang muncul di Kota Mataram, Nusa Tenggara Barat.Yaitu sebanyak 17 kasus (Dinkes Mataram, 2016).Demam tifoid dapat terjadi pada semua umur, terbanyak pada usia 3-19 tahun, sekitar 77\% dengan puncak tertinggi pada usia 10- 15 tahun (Simanjuntak, 1993).

Sanitasi, higienitas dan vaksinasi yang dapat menurunkan tingkat insidensi penyakit masih sulit diterapkan di negara berkembang termasuk Indonesia, sehingga penggunaan antibiotik dinilai sebagai cara yang paling efektif. Antibiotik yang sering digunakan dalam terapi demam tifoid adalah klorampenikol, ampisilin, kotrimkszol, norfloksasin, neomisin, ciproflaksasin dan pefloksasin (Mirza dkk., 2000).

Mutasi genetik bakteri menyebabkan terjadinya peningkatan resistensi bakteri terhadap banyak antibiotik akibat pemakaian antibiotik yang tidak prosedural dan tidak terkontrol (Mirza dkk., 2000). Pada 2007 sekitar $6,8 \%$ dari isolatSalmonella typhii telah resisten terhadap ketiga obat lini pertama yaitu: ampicillin, kloramfenikol, dan kotrimoksazol. (Hatta,dkk., 2007).Oleh karena masalah - masalah tersebut, maka dibutuhkan beberapa tindakan untuk menguranginya, diantaranya dengan mengontrol penggunaan antibiotik. Sejak lama, tumbuhan dan hewan telah menjadi sumber alami untuk menjaga kesehatan masyarakat, Menurut WHO sekitar $80 \%$ terutama di negara berkembang (Setiadi, 2013; Hastari, 2012). Pemanfaatan organisme sebagai alternatif antimikroba salah satunya adalah dengan menggunakan cacing tanah.Penelitian terhadap kemampuan antimikroba terhadap bakteri yang tergolong enterobacteriaceae (Escherichia coli, Salmonella typhi, Staphylococcus aureus, dan Vibrio cholerae) yang dimiliki oleh cacing tanah antara lain telah dilakukan oleh beberapa peneliti, yaitu Rohmah Y.A (2007), Jacinta Budiatuti, Elin Yulinah, dan Andreanus (1991), Joko Waluyo (2004) dan peneliti lainnya sehingga berhasil dikembangkan hingga kini, (Zohra, 2012).

Cacing tanah memiliki aktifitas antimikroba karena menghasilkan zat pengendali bakteri yang bernama lumbricin (Indriati.,dkk, 2012). Lumbricin merupakan senyawa peptida yang disusun oleh asam amino yang lengkap terutama prolin, dan secara invitro mampu menghambat bakteri seperti Eschericia coli, Salmonella, Staphylococcus aureus dan Streptococcus aureus (Popović, M., M. Grdiša And T.M. Hrženjak, 2005). Protein yang dimiliki oleh cacing tanah memiliki mekanisme antimikroba yang berbeda dengan mekanisme antibiotik. Antibiotik membunuh mikroganisme biasanya dengan dua cara, yaitu dengan menghentikan jalur metabolik yang dapat menghasilkan nutrient yang dibutuhkan oleh mikroorganisme atau menghambat enzim spesifik yang dibutuhkan untuk membantu menyusun dinding sel bakteri. Sedangkan, mekanisme yang dilakukan oleh protein yang dimiliki oleh cacing tanah adalah dengan membuat pori di dinding sel bakteri. Hal ini menyebakan sitoplasma sel bakteri menjadi terpapar dengan lingkungan luar yang dapat mengganggu aktivitas dalam sel bakteri dan menyebabkan kematian.Karena yang dirusak adalah struktur sel milik bakteri itu sendiri, sehingga lebih sulit untuk resisten (Cooper, ED.; Beschin, A.; Bilej, M., 2002).

Dikalangan masyarakat ada beberapa bentuk pengemasan yang digunakan untuk mengonsumsi cacing tanah sebagai obat antara lain sebagai pil, kapsul, ekstrak, cacing yang dikeringkan, dan jus cacing tanah (Anonim, 2015).Sedangkan dengan merebus cacing masih banyak digunakan masyarakat umum namun sedikit literatur yang tersedia mengenai itu.Berdasarkan uraian diatas perlu dilakukan penelitian tentang potensi air rebusan cacing tanah jenis Perionyx excavatus dalam menghambat pertumbuhan bakteri Salmonella typhi secara invitro.

\section{Metode Penelitian}

Penelitian ini bersifat observasional deskriptif yaitu penelitian yang menggambarkan tentang suatu keadaan secara objektif tanpa mengetahui adanya hubungan sebab akibat. Dalam penelitian survey deskriptif penelitian diarahkan untuk mendeskriptifkan atau menguraikan suatu keadaan didalam suatu komunitas atau masyarakat. Oleh sebab itu penelitian ini di sebut penelitian penjelajahan atau exploratory study (Notoatmodjo, 2002) 


\section{Hasil Penelitian}

Cacing tanah Perionyx excavatus merupakan cacing tanah jenis epigeik yang hidup di habitat yang lembab.Kulit cacing tanah memerlukan kelembaban cukup tinggi agar dapat berfungsi normal dan tidak rusak yaitu berkisar $15 \%-30 \%$. Suhu yang diperlukan untuk pertumbuhan dan perkembangbiakan antara $15^{\circ} \mathrm{C}-25^{\circ} \mathrm{C}$. Selain lembab, cacing tanah hidup di tanah yang subur dan suhunya tidak terlalu dingin. Untuk pertumbuhannya yang baik, cacing ini memerlukan tanah yang sedikit asam sampai netral atau $\mathrm{pH}$ 6-7,2. Pada lahan pengambilan sampel, tanah yang banyak mengandung cacing Perionyx excavatus berada di sekitar kandang sapi dan itik. Sedangkan pada lingkungan persawahan lebih sedikit ditemukan. Cacing tanah Perionyx excavatus menyukai tanah yang gembur atau lunak, namun pada tanah yang kering juga bisa ditemukan bila ada tumpukan sampah organik diatasnya.

\section{Hasil Pemeriksaan PotensiAir Rebusan Cacing Tanah Jenis Perionyx excavatus}

Penelitian ini merupakan penelitian deskriptif yang bertujuan untuk mengetahui potensi air rebusan cacing tanah jenis Perionyx excavatus dalam menghambat pertumbuhan bakteri Salmonella typhi secara invitro dengan uji difusi agar metode sumuran. Adapun hasil penelitian air rebusan cacing tanah dalam menghambat pertumbuhan bakteri dapat dilihat pada tabel 1 .

Tabel 1. Hasil pemeriksaan potensi air rebusan cacing tanah jenis Perionyx excavatus dalam menghambat pertumbuhan Salmonella typhi secara invitro

\begin{tabular}{|c|c|c|c|c|c|c|c|}
\hline \multirow{2}{*}{ Perlakuan } & \multicolumn{5}{|c|}{$\begin{array}{c}\text { Luas Zona } \\
\text { (mm) }\end{array}$} & $\begin{array}{c}\text { Total Hasil } \\
\text { Luas Zona }\end{array}$ & $\begin{array}{c}\text { Rata - Rata } \\
\text { Luas Zona }\end{array}$ \\
\cline { 2 - 6 } & 1 & 2 & 3 & 4 & 5 & & 0 \\
\hline T1 & 0 & 0 & 0 & 0 & 0 & 0 & 0 \\
\hline T2 & 0 & 0 & 0 & 0 & 0 & 0 & 0 \\
\hline T3 & 0 & 0 & 0 & 0 & 0 & 0 & 0 \\
\hline T4 & 0 & 0 & 0 & 0 & 0 & 0 & \\
\hline
\end{tabular}

Keterangan :

T1 - T4 : Perlakuan

$0 \quad$ :Tidak terdapat zona hambatan disekitar suspensi cacing tanah

Pada tabel diatas menunjukkan bahwa tidak terdapat hambatan pertumbuhan bakteri Salmonella typhi oleh air rebusan cacing tanah jenis Perionyx excavatus.

\section{Pembahasan}

Hasil penelitian pada tabel 4.1 menunjukkan tidak terdapat hambatan pertumbuhan bakteriSalmonella typhi oleh air rebusan cacing tanah jenis Perionyx excavatus pada setiap konsentrasi. Hal ini kemungkinan disebabkan oleh beberapa faktor, antara lain yaitu cara preparasi bahan untuk dijadikan sebagai antibakteri belum optimal. Proses pengolahan cacing tanah dengan cara direbus menggunakan hotplate selama 15 menit dengan suhu $72^{\circ} \mathrm{C}$ dianggap belum optimal dalam proses pemisahan bahan - bahan antibakteri dalam tubuh cacing tanah, karena antibakteri seperti lisosim dan alkaloid yang terdapat dalam tubuh cacing tanah dapat diikat oleh lemak (Palungkun, 1999) seperti didukung oleh hasil penelitian Astuti (2001), yang menunjukkan bahwa memang terdapat lemak dalam cacing tanah.Kadar lemak dalam cacing tanah adalah sebesar 5,69 \%. Sehingga akan berpengaruh ketika suhu yang digunakan belum cukup untuk meluruhkan lemak pada cacing tanah.

Hasil penelitian ini didukung oleh penelitian yang dilakukan oleh Teguh Bambang tahun 2013 yang menggunakan metode difusi sumuran dengan suspensi cacing tanah sebagai bahan penelitian. Pada penelitian ini cacing tanah di diblender kemudian di sentrifuge dengan kecepatan 3000 rpm selama 10 menit, lalu diambil supernatannya.Penelitian tersebut menyatakan bahwa tidak terdapat potensi antibakteri cacing tanah Perionyx excavatus.

Faktor lain yang kemungkinan mempengaruhi tidak terbentuknya zona adalah masa aktif dari antibakteri cacing tanah Perionyx excavatus sangat singkat. Menurut Jasinta, Elin dan Andreanus (1991), pada uji air rebusan cacing tanah sebagai antipiretik dan uji terhadap beberapa bakteri penyebab diare pada hewan coba tikus putih.Aktivitas antibakteri cacing tanah hanya terlihat pada serum selama 15 menit dan urin selama 5 jam setelah pemberian ekstrak.Selain itu, cairan selom cacing tanah sangat tidak stabil dan mudah terdegradasi bila pada suhu kamar $\left(26^{\circ} \mathrm{C}\right)$, dan suhu $37^{\circ} \mathrm{C}$. Cairan selom yang disimpan disuhu kamar tanpa 
menggunakan agen apa-apa, akan kehilangan aktivitas antibakterinya dalam 4 jam. Sehingga pada saat pengujian terhadap bakteri, antibakteri cacing tanah tidak aktif lagi dalam menghambat pertumbuhan bakteri Salmonella typhi(Yumaihana, 2007).

Selain itu ketebalan media yang digunakan juga sangat berpengaruh terhadap pertumbuhan mikroba. Dimana keseragaman ketebalan media akan meningkatkan akurasi hasil penelitian. Berikut beberapa faktor yang dapat mempengaruhi hasil uji senstivitas antara lain kekeruhan suspensi bakteri, waktu pengeringan / peresapan suspensi bakteri ke dalam MH agar, temperatur inkubasi, waktu inkubasi, ketebalan agar, jarak antar disk obat, potensi disk obat, dan komposisi media (Gamman, dkk. 2002).

Sedangkan menurut penelitian Zohra dkk (2010 dan 2012) membuktikan bahwa terdapat potensi antibakteri cacing tanah jenis Perionyx excavatus dalam menghambat bakteri pathogen, namun penelitian tersebut menggunakan metode maserasi ekstraksi yaitu menggunakan larutan metanol (2010) dan kloroform (2012) untuk menarik zat antibakteri yang terkandung dalam cacing tanah. Hal ini membuktikan metode dalam perlakuan bahan sangat berpengaruh terhadap hasil penelitian. Seperti dapat dilihat pada gambar yang tertera pada lampiran yang mana terbentuk koloni keruh di sekitar sumuran berisi air rebusan cacing tanah, diperkirakan tumbuhnya zona koloni bakteri yang keruh disekitar sumuran berisi rebusan, dikarenakan kurang maksimalnya perlakuan perebusan untuk menekan pertumbuhan bakteri lain yang terdapat dalam tubuh cacing tanah.

\section{Kesimpulan}

tidak terdapat hambatan terhadap pertumbuhan bakteri Salmonella typhi. Sehingga pengolahan cacing tanah jenis Perionyx excavatus dengan caradirebus selama 15 menit dengan suhu $72^{\circ} \mathrm{C}$, tidak bagus dalam proses pemisahan antibakteri pada cacing tanah. Dengan hasil penelitian ini, diharapkan dapat menjadi acuan oleh masyarakat dalam memilih cara pengolahan cacing tanah untuk dijadikan sebagai obat.

\section{Referensi}

Astuti Ari, 2001. Kandungan Lemak Kasar Cacing Tanah Lumbricus rubellus Dengan Menggunakan Pelarut Organik. Skripsi. IPB

Brenner, D.J., Krieg, N.R., Staley, J.T. 1984. Bergey's Manual Of Systematic Bacteriology. Second edition. Baltomor London. 416-429.

Brusch, J.L.2010.Typhoid Fever: Treatment \& Medicationhttp://emedicine.medscape.com/article/231135overview.

Ciptanto, Sapto dan Paramita,U. 2011. Mendulang Emas Hitam Melalui Budi Daya Cacing Tanah. Yogyakarta : Lily Publisher.

Cooper, ED.; Beschin, A.; Bilej, M. 2002. A new Model for Analyzing Antimicrobial Peptides with Biomedical Applications. Penerbit: IOS Press, $\underline{\text { ISBN No. } 1586032372 .}$

Darmadi.2008.Infeksi Nosokomial Problematika dan Pengendaliannya,5.Jakarta : Salemba medika.

Depkes RI. 2013. http://ejournal.unsrat.ac.id/index.php/jkp/articel/viewfile/7449/6994.pdf

Dinkes Kota Mataram.2016. Buletin Kewaspadaan Dini dan Respons. Mataram : Seksi Pemberantasan Penyakit dan Bencana, Bidang P3PL.

Hanafiah, A.K. 2010.Rancangan Percobaan Teori dan Aplikasi.Jakarta : PT. Raja Grafindo Persada.

Hastari, R. 2012.Uji Aktivitas Antibakteri Ekstrak Pelepah dan Batang Tanaman Pisang Ambon (Musa paradisiaca var.sapientum) Terhadap Staphylococcus aureus.Karya Tulis Ilmiah. Fakultas Kedokteran :Universitas Diponegoro Semarang.

Hatta, M., Smits, Henk, L. 2007.Detection of Salmonella typhi by nested polymerase chain reaction in blood, urine, and stool samples. The American joumal of tropical medicine and hygiene (Am J Trop Med Hyg), published in United States. 
Hawley L.B. 2003.Intisari Mikrobiologi dan Penyakit Infeksi,Terjemahan Pendit BU.Jakarta : Hipokrates.

Holt, J.G., dkk. 1994. Bergey's Manual Of Determinative Bacteriology. Ninth Edition.Williams and Wilkins.Ballimore : Maryland USA. 186, 242.

Indriati, Gustina., Mimit Sumitri., Rina Widiana. 2012. Pengaruh Air Rebusan Cacing Tanah (Lumbricus rubellus) Terhadap Pertumbuhan Bakteri Escherichia coli.Jurnal Prosiding Semirata BKS PTN-B MIPA 2012.ISBN 978-602-9115-20-8.

JacintaB,Elin Yulinah S.Andreanus AS, 1991. Uji Air Rebusan Cacing Tanah Sebagai Antipiretik dan Uji terhadap Beberapa Bakteri Penyebab Diare. ITB. Bandung.

Jawetz, M, dan Adelberg's. 2005. Mikrobiologi Kedokteran. Jakarta. Salemba Medika.

Koneman, E.W, dkk. 1992. Color Atlas and Textbook Of Diagnostic Microbiology. Fourth edition.Philadelphia : J. B. Lippincont Company.

Liana Luci, 2016. Diagnosis Laboratorium Demam Tifoid:: http://www.abclab.co.id/?p=345. Diakses Tanggal 17 Juni 2016.

Maier, RM., Pepper, IL., Gerba, CP. 2000. Environmental Microbiology.Printed in the United States of Amerika.

Mirza S, Kariuki S, Mamun KZ, Beeching NJ.and Hart CA. 2000. Analiysis of Plasmid and Cromosomal DNA of Multidrug- Resistant Salmonella enterica Serovar Typhi from Asia.Journal of Clinical Microbiology.vol 38 (4): 1449-1452.

Palungkun, R., 1999. Sukses Beternak Cacing Tanah Lumbricus rubellus.Jakarta : Penebar Swadaya.

Pelczar, M.J. dan Chan E.C.S.2006.Dasar-Dasar Mikrobiologi 1 Terjemahan Hadioetomo, Ratna Siri.Jakarta :Penerbit Universitas Indonesia Press.

Popović, M., M. Grdiša And T.M. Hrženjak. 2005.Glycolipoprotein G-90 obtained from the earthworm Eisenia foetida exerts antibacterial activity. Council Archive. 75: 119-128

Rukmana. R. 1999. Budidaya Cacing Tanah. Jakarta : Kanisius.

Setiadi, T.B. 2013.Uji Potensi Ekstrak Cacing Tanah Jenis Perionyx excavatus Dalam Menghambat Pertumbuhan Bakteri Escherichia coli Secara invitro.Mataram : Poltekkes Kemenkes Mataram.

Simanjuntak, C. 1993. Demam Typhoid, Epidemiologi dan perkembangan Penelitian. Cermin Dunia Kedokteran, No. 83. Vol. 3:52-53.

Soemarno. 2000. Isolasi dan Identifikasi Bakteri Klinik. Yogyakarta : Akademi Analis Kesehatan Yogyakarta.

Sumantri, A. 2011.Metodologi Penelitian Kesehatan. Jakarta : Kencana Prenada Media Group.

Talaro, K.P. and Talaro, A. 2002.Foundations in Microbiology, fourth edition.Mc Graw Hill.612-617. Yumaihana, 2007. Optimasi Pemisahan Dan Uji Aktivitas Protein Antibakteri Dari Cairan Selom Cacing TanahPerionyx excavatus. Fakultas Peternakan Universitas Andalas

Zohra, H, dkk. 2012. Potensi Ekstrak Cacing Biru Perionyx excavatus Sebagai Senyawa Antibakteri Pada Pelarut Kloroform Terhadap Beberapa Bakteri Patogen.Jurnal Prosiding SNSMAIP III-2012.ISBN No. 978602-98559-1-3. 